\title{
REDUCED MOTOR CONDUCTION VELOCITY OF THE ULNAR NERVE IN SPINAL CORD INJURED PATIENTS
}

\author{
By Professor Luba Stefaniwsky, M.D., F.A.P.M.R. ^ Professor David S. \\ BILOWIT, Ph.D., F.R.S.H., F.A.C.S.M. $\dagger$ and Sheo S. Prasad, M.D. $\ddagger$
}

\begin{abstract}
Twelve male patients with spinal cord injury were studied. The purpose of this study was to determine if ulnar nerve damage occurs in patients with spinal cord injury who are wheelchair bound and if so at which segment of the ulnar nerve.

The results showed significant drop in ulnar nerve conduction velocity in both segments, mid-arm to below elbow and below elbow to the wrist. There was no significant difference between quadriplegic and paraplegic. No significant correlation was found between ulnar nerve impairment and the duration of spinal cord injury.
\end{abstract}

\section{Introduction}

ULNAR nerve impairment at the elbow is a complication which may result after surgery and prolonged bed rest, after some inflammatory responses or space occupying lesions. Compression of the ulnar nerve during elbow flexion was observed as early as I892 (Gowers, I892).

\section{Purpose of the Study}

Ulnar nerve impairment may be diagnosed by electromyography and electroneurography (Checkles et al., I97I ; Upton \& McComas, I973). Publications have shown conflicting results (Goldkamp, 1967; Kyoichi et al., I975) in reporting the presence of ulnar nerve pathology. This prompted the present investigation of the nerve conduction velocity (NCV) of the ulnar nerve in subjects with spinal cord injury who spend the major part of their day in wheelchairs with their arms in a position of elbow flexion with the forearm pronated.

The study was designed to determine if the ulnar nerve damage occurs in patients with spinal cord injury who are wheelchair bound and, if so, at which segment of the ulnar nerve.

\section{Anatomy}

Below mid-arm the ulnar nerve passes posteriorly through an opening in the medial intermuscular septum behind the medial epicondyle and continues to the forearm passing between the humeral and ulnar heads of the flexor carpi ulnaris and flexor digatorum profundus. It is held in the groove behind the medial epicondyle by the fibrous common origin of the flexor muscles. This area is often called the cubital tunnel (Kopell \& Thompson, 1963). At the medial epicondyle the ulnar nerve rests directly on the bony surface and is covered by only fascia and skin. It is thus, at this point, most prone to trauma or entrapment.

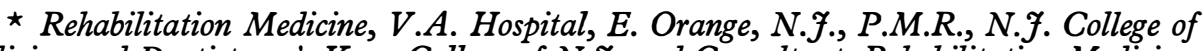
Medicine and Dentistry; $\dagger$ Kean College of N.F. and Consultant, Rehabilitation Medicine, V.A. Hospital, E. Orange, N.F.; $\ddagger$ Rehabilitation Medicine, V.A. Hospital, E. Orange, N.f. (at the time of the study). 
Also when the elbow is flexed the tunnel is narrowed and the nerve compressed (Apfelberg \& Larson, I973).

\section{Materials and Methods}

Twelve male subjects with spinal cord injury ranging in age from 25 to 63 years were studied. The most recent injury occurred 3 years ago; the oldest, 32 years ago. The mean length of time of the injuries was 10.4 years. Twelve normal male volunteers between the ages of 24 and 58 years were used to acquire control data.

All subjects were tested under identical conditions in the same room which was kept at a constant temperature of $79-80^{\circ} \mathrm{F}$. The TECA Electromyograph (Model TE4) was used to determine the NCV. The ulnar nerve was stimulated by supramaximal impulse or $0 \cdot I$ milliseconds duration and the resultant evoked potential was recorded by placing a surface electrode on the belly of the abductor digiti minimi. The ulnar nerve was stimulated at three points: $\mathrm{I}$, proximally at the mid-arm just above the origin of the medial head of the triceps $(M A) ; 2$, I to $2 \mathrm{~cm}$ below the medial epicondyle of the ulna (BE); $3, \mathrm{I} \mathrm{cm}$ above the wrist crease just lateral to the tendon of the flexor carpi ulnaris (W).

\section{Results}

The only main factor which proved to be significant was the group factor. Specifically, the normal group's NCV was significantly faster than the spinal cord injury group at the 0.0 I level of confidence (Tables I and II).

\section{Discussion}

The levels of spinal injury varied from $\mathrm{C}_{5}$ to TII. It was therefore possible that higher level injuries having sequelae involving upper extremities might modify NCV. Therefore, a supplementary analysis (three-way analysis of variance with repeated measures on the last two factors) was carried out. The results revealed that there was no significant difference between the high level quadriplegia and the lower level paraplegic.

It was also possible that length of time since onset of injury might be a critical variable affecting conduction velocity. A correlation analysis carried out between duration of injury and NCV for both segments and both arms showed no significant correlations (Table III).

TABLE I

\begin{tabular}{lcccccc}
\hline & \multicolumn{2}{c}{ Left ulnar nerve } & \multicolumn{3}{c}{ Right ulnar nerve } \\
\cline { 2 - 5 } \cline { 5 - 6 } & BE to W & MA to BE & & BE to W & MA to BE & M \\
\hline Normal & $62 \cdot 9$ & $62 \cdot 4$ & & $6 \mathrm{I} \cdot 9$ & $6 \mathrm{I} \cdot 0$ & $62 \cdot \mathrm{I}$ \\
Patients & $49 \cdot 9$ & $48 \cdot 9$ & & $52 \cdot \mathrm{I}$ & $50 \cdot 9$ & $50 \cdot \mathrm{I}$ \\
\hline
\end{tabular}


TABLE II

Summary table of ANOVA

\begin{tabular}{|c|c|c|c|c|c|}
\hline \multicolumn{2}{|c|}{ Source } & SS & d.f. & MS & $F$ ratio \\
\hline \multicolumn{2}{|c|}{ Between subjects } & 6305 & 23 & - & - \\
\hline \multicolumn{2}{|c|}{ A (group) } & 3450 & I & 3450 & $26 \cdot 58^{\star}$ \\
\hline \multicolumn{2}{|c|}{ Subj. within groups } & 2855 & 22 & $129 \cdot 8$ & - \\
\hline \multicolumn{2}{|l|}{ Within subjects } & 2276 & 72 & - & - \\
\hline \multicolumn{2}{|l|}{ B (segment) } & 38 & I & 38 & $\mathrm{I} \cdot \mathrm{I} 5$ \\
\hline \multicolumn{2}{|l|}{$\mathrm{AB}$} & 8 & I & 8 & 0.24 \\
\hline \multicolumn{2}{|c|}{$\mathrm{B} \times$ subj. within groups } & 724 & 22 & $32 \cdot 9$ & - \\
\hline \multicolumn{2}{|c|}{$\mathrm{C}(\mathrm{arm})$} & 17 & $\mathbf{I}$ & 17 & $0 \cdot 40$ \\
\hline \multirow{2}{*}{\multicolumn{2}{|c|}{$\begin{array}{c}\mathrm{AC} \\
\mathrm{C} \times \text { subj. within groups }\end{array}$}} & 97 & I & 97 & $2 \cdot 29$ \\
\hline & & 932 & 22 & 424 & - \\
\hline \multirow{2}{*}{\multicolumn{2}{|c|}{$\begin{array}{l}\mathrm{BC} \\
\mathrm{ABC}\end{array}$}} & 2 & I & 2 & 0.09 \\
\hline & & 4 & I & 4 & 0.29 \\
\hline \multicolumn{2}{|c|}{$\mathrm{BC} \times$ subj. within groups } & 454 & 22 & $20 \cdot 6$ & - \\
\hline \multicolumn{6}{|c|}{$\begin{aligned} \mathrm{F} \text { value: } & \mathrm{F} \mathrm{O} . \mathrm{OI}(\mathrm{I}, 22)=7.95 \\
& \star \mathrm{P}=0.0 \mathrm{I}\end{aligned}$} \\
\hline \multicolumn{6}{|c|}{ TABLE III } \\
\hline \multicolumn{6}{|c|}{ Correlation coefficients } \\
\hline $\begin{aligned} \text { Left: } & \mathrm{BE} \text { to } \mathrm{W} \\
& \mathrm{MA} \text { to } \mathrm{BE}\end{aligned}$ & $\begin{array}{l}r=-0.108 \\
r=-0.115\end{array}$ & \multicolumn{3}{|c|}{$\begin{aligned} \text { Right: } & \mathrm{BE} \text { to } \mathrm{W} \\
& \mathrm{MA} \text { to } \mathrm{BE}\end{aligned}$} & $\begin{array}{l}r=-0.168 \\
r=-0.315\end{array}$ \\
\hline
\end{tabular}

\section{SUMMARY}

The results showed a significant drop in NCV among spinal cord injury patients (Table II). However, there was no difference between the NCV in the different areas of either arm (Table I).

If the slower velocity was due only to ulnar nerve entrapment in the cubital tunnel, we could expect a reduction of velocity only in the upper segment, mid-arm to elbow. But there was no significant difference in segmental involvement. The $\mathrm{F}$ ratio was 0.09 . Therefore, damage must occur to both segments of the arm.

Damage to the lower segment may be due to direct pressure of the forearm against the armrest of the wheelchair. If so, the damage must occur in a short period of time (Barr, 1974) because there was little difference between subjects injured 3,19 and 32 years ago.

\section{RÉSUMÉ}

Nous avons étudié douze hommes internés qui sont victimes d'une blessure à la moelle épinière. Le but de notre étude était de déterminer s'il y aurait de la détérioration au nerf ulnaire dans ceux qui ont une blessure à la moelle épinière et qui se transportent en chaise roulante, et, si c'est le cas, quelle partie du nerf ulnaire serait atteinte.

D'après les résultats, nous voyons une brusque diminution de lat vélocité de la conduction dans le nerf ulnaire dans les deux parties, milieu du bras jusqu'au, dessous du coude et au, dessous du coude jusqu'au poignet. Il n'y avait pas degrandes différences entre les paraplégiques et les quadriplégiques. Nous n’avons pas trouvé de rapport signi- 
ficatif entre l'affaiblissement du nerf ulnaire et la durée du temps de la blessure à la moelle épinière.

\section{ZUSAMMENFASSUNG}

Zwölf männliche Patienten wurden untersucht. Der Zweck dieser Arbeit war festzustellen, ob Schädigung von ulnar nerven bei Kranken mit Verletzung der Wirbelsäule vorkommt, welche gezwungen sind im Rollstuhl zu sitzen, und wenn dies der Fall sein sollte, an welcher Stelle des Nervus ulnaris.

Das Endergebnis zeigte bedeutsame Senkung in der Geschwindigkeit der Weiterleitung des ulnar nerven in beiden Teilen, mittel arm bis unter dem Ellenbogen und abwärts vom Ellbogen bis zum Handgelenk. Es erwies sich kein bedeutsamer Zusammenhang zwischen der Länge der Verletzung der Wirbelsäule und der Schädigund des ulnar Nerv.

\section{REFERENCES}

Apfelberg, D. B. \& Larson, S. J. (1973). Dynamic anatomy of the ulnar nerve at the elbow. Plastic and Reconstruction Surgery, 5I, 76-8I.

BARR, J. S. (1974). Letters to the Editor: post-surgical ulnar neuropathy. $\mathcal{F} A M A, \mathbf{2 2 8}$, I099.

Checkles, N., Russakov, A. D. \& Piero, D. L. (I97I). Ulnar nerve conduction velocityeffect of elbow position in measurement. Archives of Physical Med., 52, 362-365.

GolDKAMP, O. (1967). Electromyography and nerve conduction studies in 116 patients with hemiplegia. Archives of Physical Med., 48, 59-63.

Gowers, W. R. (1892). A Manual of Diseases of the Nervous System, 2nd Ed., Vol. I. Churchill, London.

Kopell, H. \& ThOMpson, W. (1963). Peripheral Entrapment Neuropathies, Williams and Wilkins Co., Baltimore.

Kyoichi, T. M., Narayan, G., Kupulka, C. \& Basmajian, J. V. (1975). Slowing of nerve conduction velocity in hemiplegia: possible factors. Archives of Physical Med., 56, 285-289.

Upton, A. \& McComas, A. (1973). The double crush in nerve entrapment syndrome. Lancet, 2, 359-362.

WADSWORTh, T. G. \& Williams, J. R. (I973). Cubital tunnel external compression syndrome. British Med. F., I, 662-666. 